\title{
ANALISIS BUTIR SOAL URAIAN MATA KULIAH PENGANTAR AKUNTANSI 1
}

\author{
Budi Mulyati \\ Universitas Banten Jaya, \\ Serang Indonesia \\ budimulyati@unbaja.ac.id
}

\begin{abstract}
The purpose of this study was to analyze the items in the form of essay items, given as a final exam in subject of introductory accounting 1. This question was given to nineteen students in semester 1 of the 2020-2021 academic year. This study used a descriptive method with a quantitative approach. For the purposes of analysis, the item analysis technique was used, which consisted of an analysis of the level of difficulty of the items and the analysis of the differentiating power of the items. Based on the results of the analysis, the results obtained that the questions made had an index of difficulty level as an easy question of $50 \%$ and an average question of $50 \%$. And based on the results of the analysis of the differentiating power index, the questions included as questions that needed to be revised were $33.3 \%$ and questions that were not good were $67.7 \%$.
\end{abstract}

Keyword: Item Analysis, Essay Item

\section{PENDAHULUAN}

Konsep dasar akuntansi menjadi salah satu hal yang harus dikuasai untuk dapat memahami akuntansi secara utuh. Pemahaman yang kurang terhadap dasar akuntansi akan menyebabkan kesulitan untuk mempelajari akuntansi (Sakdiah \& Silalahi, 2017). Secara umum materi akuntansi keuangan yang dipelajari mahasiswa di tingkat perguruan tinggi dimulai dengan diberikannya mata kuliah pengantar akuntansi atau dasar akuntansi. Dimana salah satu tujuan pemberian mata kuliah ini adalah dikuasainya materi tentang akuntansi untuk perusahaan jasa, dagang dan manufaktur. Namun di dalam Chesaria, R.D, Adi, W., \& Muchsini, B. (2015) secara umum dinyatakan bahwa tingkat kesulitan belajar yang paling tinggi adalah justru di saat mempelajari materi tentang perusahaan jasa dengan sub bahasan yang berupa 1) pengelolaan dokumen transaksi, 2) Pencatatan transaksi dalam jurnal, 3) Penggolongan transaksi dalam buku besar, dan 4) penyusunan laporan keuangan perusahaan jasa.

Beberapa penyebab yang membuat sulitnya mempelajari akuntansi berasal dari faktor internal dan faktor eksternal (Kafid, M, 2007), (Sari, M.A., 2017). Penelitian lain dari Kusuma, A.S (2017) menyebutkan bahwa dua faktor yang mempengaruhi kesulitan belajar yaitu faktor proses pembelajaran dan faktor lingkungan. Dimana selama proses 
pembelajaran ada kecenderungan tidak terjadi pembelajaran aktif dan kreatif, adanya kebiasaan mencontek serta jarang terjadi diskusi antara guru dan siswa. Dan lingkungan siswa yang berupa kebiasaan bermain gadget secara berlebihan hingga gangguan dalam keluarga menjadi beberapa faktor lain yang membuat siswa sulit mempelajari akuntansi.

Hasil penelitian yang menyebutkan tentang faktor yang mempengaruhi kesulitan belajar akuntansi siswa ternyata relevan dengan faktor yang mempengaruhi hasil belajar akuntansi untuk mahasiswa di perguruan tinggi. Diantaranya minat dan kesukaan mahasiswa, latar belakang pendidikan serta kualitas pembelajaran (Apridasari, E. 2016); (Biduri, S. 2016). Hal ini berarti bahwa minat yang kurang serta tidak paralelnya latar belakang pendidikan sebelumnya akan membuat mahasiswa kesulitan untuk mempelajari materi dalam bidang akuntansi.

Terdapat hasil analisis data penelitian yang lain (Dayamsari, $\mathrm{P}$. 2012:55), disebutkan bahwa banyak mahasiswa yang tidak paham terhadap materi yang diajarkan, dalam hal ini materi yang terdapat dalam mata kuliah pengantar akuntansi, baik akuntansi untuk perusahaan jasa, dagang maupun perusahaan manufaktur.
Adapun lingkup materi yang terdapat dalam mata kuliah pengantar akuntansi sebelum mempelajari siklus akuntansi di perusahaan jasa, dagang dan manufaktur, terdiri dari materi tentang konsep persamaan akuntansi. Melalui persamaan akuntansi, mahasiswa mulai mengenal konsep akun terutama akun yang terdapat dalam kelompok neraca. Persamaan akuntansi menjadi dasar dalam memahami akuntansi keuangan secara umum karena melalui konsep persamaan akuntansi mahasiswa akan terbiasa dengan istilah sisi kanan dan kiri atau lazim disebut dengan sisi debit dan kredit. Dimana berdasarkan hasil observasi peneliti selama tahun 2019-2020 di Universitas Banten Jaya, masih saja ditemukan fakta tentang pemahaman awal mahasiswa yang keliru tentang kedua konsep tersebut.

Kekeliruan yang umum ditemukan adalah adanya pemaknaan bahwa debit artinya masuk sedangkan kredit artinya keluar (adanya arus kas keluar). Dapat dikatakan bahwa asumsi awal mahasiswa tentang akuntansi masih seputar arus kas keluar dan arus kas masuk. Dan ketika dikenalkan dengan konsep utang dan modal, mahasiswa mengalami kebingungan tentang konsep debit dan kredit. Namun demikian hal tersebut dapat dijadikan feed back bagi pengajar untuk 
mulai menyusun pembelajaran sehingga pemaknaan yang masih keliru dapat diluruskan.

Namun demikian untuk dapat mengetahui tentang materi apa saja yang masih dianggap sulit oleh mahasiswa setelah mahasiswa belajar tentang akuntansi, maka diperlukan analisis lain yang berkaitan dengan telaah materi sulit. Hal ini tentu saja akan sangat bermanfaat terutama untuk bahan evaluasi bagi pengajar tentang materi apa saja yang memerlukan perhatian dan penekanan lebih besar dibanding materi yang lainnya.

Bahan evaluasi ini sangat diperlukan, karena dengan kondisi belajar secara daring ini, pengajar masih berupaya untuk mencari gaya belajar yang sesuai dengan kebutuhan para mahasiswa yang masih tidak memperbolehkan untuk belajar tatap muka. Karena dengan kondisi yang masih mengharuskan untuk tetap belajar di rumah dapat menyebabkan dampak yang kurang baik. Seperti misalnya adanya ketidakpuasan mahasiswa terhadap pembelajaran jarak jauh karena mahasiswa merasa tidak dapat mamantau perkembangan pembelajaran jarak jauh dengan mudah, tidak dapat memperoleh materi pembelajaran dan mempelajari materi dengan mudah, (Napitupulu, R.M. 2020).
Dalam penelitian Sari, S.P., Aryansyah, J.E., \& Sari, K. (2020), bahwa mahasiswa di Kota Palembang memiliki tingkat resilensi yang sedang artinya mahasiswa masih gelisah dalam menghadapi berbagai masalah dan belum mampu menganalisa dengan baik berbagai masalah tersebut selama melakukan proses pembelajaran dari rumah. Namun demikian, menurut hasil penelitian tersebut, mahasiswa juga memiliki keyakinan bahwa masalah yang sedang dihadapi akan mampu untuk diselesaikan serta memiliki keinginan untuk mengoptimalkan kemampuannya agar mendapatkan hasil yang maksimal.

Dampak lain yang dirasakan mahasiswa saat melakukan perkuliahan secara daring di saat pandemic covid-19 diantaranya 1) pembelajaran daring masih membingungkan mahassiwa, mahasiswa menjadi pasif, kurang kreatif dan kurang produktif, 3) penumpukan informasi/konsep pada mahasiswa kurang bermanfaat, 4) mahasiswa mengalami stress. Namun demikian, dampak positifnya adalah adanya peningkatan kemampuan literasi bahasa mahasiswa, (Argaheni, N.B., 2020). Bahkan pembelajaran daring sebagai konsekuensi secara tidak langsung adanya covid 19 membuat kompetensi mahasiswa menurun, karena antara pemberian teori 
dan praktek yang tidak seimbang (Kusmiati, L., \& Rahadi, D.R. 2020).

\section{METODE PENELITIAN}

Kajian ini menggunakan metode analisis butir soal secara kuantitatif. Dimana peneliti melakukan telaah butir soal dalam bentuk soal uraian untuk mata kuliah Pengantar Akuntansi 1. Analisis butir soal yang dilakukan terdiri dari analisis tingkat kesukaran butir soal dan analisis daya beda butir soal.

Adapun formula yang digunakan untuk menghitung tingkat kesukaran butir soal uraian adalah sebagai berikut,

Mean $=\frac{\text { Jumah skor.siswa peserta tes pada suatu soal }}{\text { Jumlah peserta didik yang mengikutites }}$

Tingkat Kesuli $\tan =\frac{\text { Mean }}{\text { Skor maksimum yang ditetapkan }}$

Sumber: Sunarti \& Rahmawati, S. (2014)

Adapun kriteria hasil perhitungan tingkat kesulitan butir soal dapat diklasifikasikan menjadi jenis soal yang mudah, sedang atau sulit. Penggolongan jenis soal dapat dilihat di tabel berikut ini,

\section{Tabel 1. Klasifikasi Tingkat} Kesukaran Butir Soal

\begin{tabular}{cc}
\hline Indeks Kesulitan & Penilaian Soal \\
\hline 0,29 ke bawah & Soal Sukar \\
$0,30-0,69$ & Soal Sedang \\
0,70 ke atas & Soal Mudah \\
\hline
\end{tabular}

Sumber: Subino dalam Gantini, P. \& Suhendar, D. (2017)

Adapun formula yang digunakan untuk menghitung tingkat daya beda butir soal adalah sebagai berikut,

$$
D P=\frac{\text { Mean kelompok atas }- \text { Mean kelompok bawah }}{\text { Skor maksimum soal }}
$$

Sumber: Sunarti \& Rahmawati, S. (2014)

Hasil perhitungan daya beda butir soal dinyatakan dengan angka indeks dengan rentang 0,00-1,00. Adapun klasifikasi untuk setiap rentang dapat dilihat di tabel berikut,

Tabel 2. Klasifikasi Daya Beda

\begin{tabular}{cc}
\hline DP & Penilaian Soal \\
\hline $0,40-$ ke atas & Soal sangat baik \\
$0,30-$ ke atas & Soal cukup baik \\
$0,20-0,29$ & Soal Perlu direvisi \\
$0,19-$ ke bawah & Soal tidak baik \\
\hline
\end{tabular}
Sumber: Subino dalam Gantini, P. \& Suhendar, D. (2017).

Hasil skor yang diperoleh berdasarkan hasil ujian akhir semester. Analisis dilakukan terhadap seluruh lembar jawaban yang diisi oleh mahasiswa tingkat pertama. Jumlah mahasiswa yang mengisi lembar soal ujian sebanyak 19 orang mahasiswa.

\section{HASIL PENELITIAN DAN PEMBAHASAN}

Soal yang diberikan sebagai soal ujian akhir semester ini merupakan soal yang dibuat secara parallel dengan soal pada tahun akademik sebelum dilakukannya pembelajaran daring. Soal yang dibuat untuk soal ujian akhir semester dibuat dalam bentuk soal uraian yang terdiri dari satu ilustrasi soal siklus akuntansi yang dimulai dari daftar neraca 
saldo kemudian ada tambahan informasi yang akan digunakan untuk membuat jurnal penyesuaian.

Berdasarkan soal tersebut mahasiswa harus membuat jurnal penyesuaian, neraca lajur, laporan keuangan (yang terdiri dari laporan laba rugi, laporan perubahan modal dan neraca) serta jurnal penutup. Lama waktu pengerjaannya adalah selama 3 SKS atau setara dengan 150 menit.

Berdasarkan hasil penskoran, diperoleh nilai untuk 19 mahasiswa yang diurutkan dari skor yang paling rendah hingga yang paling tinggi, sebagai berikut,

Tabel 3. Skor Peserta Tes

\begin{tabular}{llcc}
\hline No & \multicolumn{1}{c}{$\begin{array}{c}\text { Inisial } \\
\text { Nama } \\
\end{array}$} & Skor & $\begin{array}{c}\text { Jenis } \\
\text { Keserta Tes }\end{array}$ \\
& & \\
\hline 1 & AK & 60 & \\
2 & DR & 60 & \\
3 & GT & 60 & \\
4 & SA & 60 & \\
5 & UQ & 60 & Kelompok \\
6 & SS & 60 & Bawah \\
7 & MI & 63 & \\
8 & NU & 63 & \\
9 & AS & 64 & \\
\hline 10 & D & 64 & \\
\hline 11 & DW & 65 & \\
12 & DJ & 67 & \\
13 & RY & 67 & \\
14 & BN & 70 & Kelompok \\
15 & DF & 70 & Atas \\
16 & At & 74 & \\
17 & Se & 77 & \\
18 & Ri & 97 & \\
19 & ES & 100 & \\
\hline Sumber: & Data Diolah $(2020)$ & \\
& & & \\
\hline
\end{tabular}

Berdasarkan data hasil penskoran, diperoleh informasi bahwa secara umum, rata-rata hasil ujian akhir semester sebesar 68,5. Dikarenakan jumlah peserta tes sebanyak 19 orang (ganjil), maka untuk memudahkan perhitungan, peserta tes yang berada di nomor urut 10 akan dihilangkan dari proses analisis.

Analisis tingkat kesukaran butir soal digunakan dengan tujuan untuk bisa mengetahui apakah butir soal yang dibuat termasuk soal yang sulit atau mudah. Hasil perhitungan yang diperoleh dalam bentuk nilai indeks dengan nilai antara 0,00-1.00.

Berdasarkan hasil perhitungan, diperoleh nilai indeks kesukaran butir soal sebagai berikut

Tabel 4. Nilai Indeks Tingkat

\section{Kesukaran}

\begin{tabular}{ccc}
\hline $\begin{array}{c}\text { No } \\
\text { Butir } \\
\text { Soal }\end{array}$ & $\begin{array}{c}\text { Nilai Indeks } \\
\text { Tingkat } \\
\text { Kesukaran }\end{array}$ & Kategori \\
\hline 1 & 0,83 & Mudah \\
2 & 0,72 & Mudah \\
3 & 0,73 & Mudah \\
4 & 0,56 & Sedang \\
5 & 0,50 & Sedang \\
6 & 0,52 & Sedang \\
\hline Sumber: Data Diolah (2020) \\
Berdasarkan hasil & perhitungan, \\
diketahui bahwa butir soal yang dibuat & \\
memiliki tingkat kesukaran mudah dan \\
sedang. Adapun sub bahasan yang \\
memiliki nilai indeks tingkat kesukaran
\end{tabular}


yang sedang terdapat pada nomor 4, 5 dan

6. Dimana sub bahasan dalam butir soal nomor ini yakni tentang laporan perubahan modal, neraca dan jurnal penutup. Sedangkan sub bahasan yang memiliki nilai indeks kesukaran soal yang mudah terdapat dalam butir soal 1,2 , dan 3. Dimana sub bahasan dalam butir soal ini adalah tentang jurnal penyesuaian, neraca lajur dan laporan laba rugi.

Hasil perhitungan yang bertujuan untuk menganalisis bagaimana butir soal dapat digunakan untuk menilai tingkat daya beda butir soal dapat dilihat dalam tabel berikut ini,

Tabel 5. Nilai Indeks Daya Beda

\begin{tabular}{ccc}
\hline No Soal & ID & Kategori \\
\hline 1 & 0,03 & Soal tidak baik \\
2 & 0,16 & Soal tidak baik \\
3 & 0,22 & Soal perlu direvisi \\
4 & 0,11 & Soal tidak baik \\
5 & 0,15 & Soal tidak baik \\
6 & 0,25 & Soal perlu direvisi \\
\hline
\end{tabular}

Sumber: Data Diolah (2020)

Berdasarkan hasil perhitungan indeks daya beda, diperoleh informasi bahwa soal yang memiliki kategori sebagai soal tidak baik yakni terdapat dalam butir soal nomor 1, 2, 4, dan 6. Butir soal ini merupakan butir soal yang terdiri dari sub bab tentang jurnal penyesuaian, neraca lajur, laporan perubahan modal serta jurnal penutup. Sedangkan butir soal yang termasuk dalam kategori perlu direvisi yakni terdapat dalam butir soal nomor 3 dan 5 . Sub bab dalam butir soal ini yakni tentang laporan laba rugi dan neraca.

Secara umum butir soal yang ditanyakan memiliki content pertanyaan yang relevan dengan materi yang telah disampaikan dalam perkuliahan, namun demikian dari butir pertanyaan yang diberikan, terdapat empat butir soal, dari enam butir soal, yang memiliki nilai indeks daya yang sangat rendah. Artinya, butir soal tersebut tidak dapat membedakan kemampuan kelompok mahasiswa.

Dibandingkan dengan hasil pembelajaran di tahun akademik sebelumnya, dimana perolehan skor rerata lebih baik dari tahun akademik 2020/2021. Diperkirakan pengajar kurang optimal dalam mengontrol proses pembelajaran secara daring. Kendala utama yang ditemui selama proses perkuliahan adalah sulitnya mengontrol kesiapan mahasiswa sebelum dan selama proses pembelajaran. Selain itu terdapat kendala lain seperti kuota dan sinyal yang kurang baik.

Kendala ini pernah dikaji oleh Nainggolan, J., Pardede, S., \& Butarbutar, I. (2020) bahwa berdasarkan hasil survey diperoleh informasi bahwa kendala yang dialami dosen dalam pelaksanaan perkuliahan online diantaranya banyak 
mahasiswa yang tidak mempunyai kuota internet, lingkungan tempat tinggal yang tidak memadai dalam melakukan perkuliahan online, jaringan internet yang tidak merata, penyampaian materi pembelajaran yang tidak maksimal dan banyaknya keluhan materi pembelajaran yang sulit dimengerti. Hal serupa pernah dikaji pula oleh Syaharudin, S (2020); Kurniawan, M.W., \& Zarnita, Y. (2020); Fikri, M., dkk (2021); Dewi, S.M. (2020). Kendala ini tidak hanya dialami oleh dosen yang mengajar di perguruan tinggi, namun juga dialami oleh guru di tingkat sekolah. Rigianti, H.R. (2020) disebutkan bahwa kendala yang dialami guru selama pembelajaran daring yaitu kendala dalam hal penggunaan aplikasi pembelajaran daring, minimnya akses jaringan internet, sulitnya melakukan pengelolaan pembelajaran, kesulitan dalam pelaksanaan penilaian serta kurangnya pengawasan. Bahkan dapat dikatakan pembelajaran daring tidak efektif diterapkan pada siswa di sekolah dikarenakan tidak memadainya saran dan prasaran yang diperlukan, (Wulandari, dkk: 2020).

\section{SIMPULAN DAN SARAN}

\section{Simpulan}

Berdasarkan hasil analisis dapat disimpulkan bahwa butir soal yang digunakan sebagai perangkat soal ujian akhir semester mata kuliah pengantar akuntansi 1 di tahun akademik 2020/2021 diihat dari tingkat kesukaran butir soal dan daya beda butir soal sebagai berikut;

1. Butir soal yang dibuat termasuk dalam butir soal yang tingat kesulitan soalnya sedang dan mudah. Terdapat $50 \%$ Butir soal yang tingkat kesulitannya sedang dan $50 \%$ butir soal yang tingkat kesulitannya mudah.

2. Butir soal yang dibuat termasuk butir soal yang harus diperbaiki dan butir soal yang tidak baik. Sebanyak 33\% merupakan butir soal yang perlu diperbaiki dan terdapat $67 \%$ butir soal yang tidak baik karena tidak bisa membedakan antara mahasiswa yang memiliki kemampuan tinggi dan mahasiswa yang memiliki kemampuan lebih rendah.

3. Penelitian ini menemui beberapa kendala yang berkaitan dengan proses perkuliahan. Kendala yang ditemui berupa kendala dalam pengelolaan kelas dan kendala ketersediaan kuota dan sinyal internet. 


\section{DAFTAR PUSTAKA}

\section{a. Dari buku teks:}

Gantini, P. \& Suhendar, D. (2017). Penilaian Hasil Belajar. Jakarta: Erlangga.

Sunarti \& Rahmawati, S. (2014). Penilaian dalam Kurikulum 2013. Membantu Guru dan Calon Guru Mengetahui Langkah- Langkah Penilaian Pembelajaran. Yogyakarta. CV. Andi Offset.

\section{b. Dari skripsi/Tesis/Disertasi}

Dayamsari, P. (2012). Faktor- factor yang mempengaruhi Pemahaman Mahasiswa Program Studi Akuntansi Angkatan Tahun 2009 terhadap Mata Kuliah Pengantar Akuntans pada Perguruan Tinggi Swasta di Seberang Ulu II Palembang. Skripsi. Universitas Muhammadiyah Palembang. Tersedia online: http://repository.umpalembang.ac.id/id/eprint/1217/1/SK RIPSI1023-1710113252.pdf.

Kusuma, A.S. (2017). Analisis Kesulitan Belajar Akuntansi Siswa Kelas XII IPS SMA N 1 Sukodono Kabupaten Sragen Tahun Ajaran 2017/2018. Skripsi. Universitas Muhammadiyah Surakarta. Tersedia online: http://eprints.ums.ac.id/57376/15/NA SKAH\%20PUBLIKASI.pdf.

Sari, M.A. (2018). Analisis Faktor-Faktor Kesulitan Belajar Akuntansi Perusahaan Jasa Mahasiswa Program Studi Pendidikan Akuntansi Angkatan 2016 Fakultas Keguruan dan Ilmu Pendidikan Universitas Muhammadiyah Surakarta. Skripsi. Universitas Muhammadiyah Surakarta. Tersedia online: http://eprints.ums.ac.id/60457/10/NA SKAH\%20PUBLIKASI.pdf.

\section{c. Dari Jurnal}

Apridasari, E. (2016). Faktor-Faktor yang Mempengaruhi Hasil Belajar Mahasiswa dalam Mata Kuliah Bidang Akuntansi. Dewantara, 2, 230-240.

Argaheni, N.B. (2020). Sistematik Review: Dampak Perkuliahan Daring saat Pandemi Covid-19 terhadap Mahasiswa Indonesia. Placentum Jurnal Ilmiah Kesehatan dan Aplikasinya, 8 (2), 99-108.

Chesaria, R.D., Adi, W., \& Muchsini, B. (2015). Analisis Faktor- Faktor Penyebab Kesulitan Belajar Akuntansi Perusahaan Jasa Siswa Kelas X Akuntansi SMK Negeri 1 Surakarta Tahun Ajaran 2014/2015. Jurnal Tata Arta, 1 (1), 94-102.

Dewi, S.N. (2020). Dampak Covid 19 terhadap Pembelajaran Daring di Perguruan Tinggi. Jurnal Pendidikan Ilmu Pengetahuan Sosial, 12 (2), 8793.

Fikri, M., Faizah, N., Elian, S. A., Rahmani, R., Ananda, M. Z., \& Suryanda, A. (2021). Kendala Dalam Pembelajaran Jarak Jauh di Masa Pandemi Covid19: Sebuah Kajian Kritis. Jurnal Education and Development, 9(1), 145-145.

Kafid, M. (2007). Faktor-Faktor yang Mempengaruhi Kesulitan Belajar Akuntansi. Dinamika Pendidikan, 2 (1), 1-30.

Kusmiati, L. \& Rahadi, D.R. (2020). Pengembangan Kompetensi Mahasiswa di Masa Pandemic Covid19. Jurnal Manajemen Bisnis, 33 (2), 92-101.

Nainggolan, J., Pardede, S., \& Butar-butar, I. (2020). Survei Kendala Dosen Fakultas Keguruan dan Ilmu Pendidikan Universitas HKBP Nommensen dalam Pelaksanaan Perkuliahan Online. Jurnal Suluh Pendidikan, 8 (2), 1-8. 
Napitupulu, R.M. (2020). Dampak Pandemi Covid-19 terhadap Kepuasan Pembelajaran Jarak Jauh. Jurnal Inovasi Teknologi Pendidikan, 7 (1), 23-33.

Rigianti, H.A. (2020). Kendala Pembelajaran Daring Guru Sekolah Dasar di Kabupaten Banjarnegara. Elementary School, 9 (2), 297-302.

Sakdiah, K. \& Silalahi, C.A.P. (2017). Pengaruh Persepsi Mahasiswa dalam Kesulitan Belajar Akuntansi terhadap Motivasi Belajar Mahasiswa. Owner: Riset \& Jurnal Akuntansi, 1 (1), 5761.

Sari, S.P., Aryansayah, J.E., \& Sari, K. (2020). Resiliensi Mahasiswa dalam Menghadapi Pandemi Covid 19 dan Implikasinya terhadap Proses Pembelajaran. Indonesian Journal of Guidance and Counseling: Teori and Application, 9 (1), 17-22.

Wulandari, M. A., Arga, H. S. P., Kelana, J. B., Altaftazani, D. H., \& Ruqoyyah, S. (2020). Analisis Pembelajaran "Daring" Pada Guru Sekolah Dasar di Era Covid-19. Jurnal Ilmiah P2M STKIP Siliwangi, 7(2), 164-168.

\section{d. Dari Proceeding}

Biduri, S. (2016). Pengaruh Pemahaman Mahasiswa Akuntansi Terhadap Konsep Dasar Akuntansi Dengan Latar Belakan Sekolah Menengah Yang Berbeda Pada Universitas Muhammadiyah Sidoarjo - Jawa Timur. Prosiding, Seminar Nasional Ekonomi dan Bisnis \& Call for Paper yang diselenggarakan oleh FEB UMSIDA, tanggal 17 September 2016. Sidoarjo: Universitas Muhammadiyah Sidoarjo.

\section{d. Dari Internet}

Syaharuddin, S. (2020). Pembelajaran Masa Pandemi: Dari Konvensional Ke Daring. Pembelajaran Masa Pandemi: Dari Konvensional Ke Daring. Diakses tanggal 22 Juni 2021 dari http://eprints.ulm.ac.id/9150/1/1.\%20 Pembelajaran\%20Masa\%20Pandemi

Dari\%20Konvensional\%20ke\%20Da ring 
